\title{
Analyzing Economic Sustainability of Market Gardening and Rice Farms in Southwest Benin under FAFA Project
}

\author{
Fanougbo Avoce Viagannou ${ }^{1,2}$ \\ ${ }^{1}$ ENEAM/University of Abomey-Calavi (UAC), Benin \\ 2 LEP- Laboratory of Public Economy, Benin \\ Correspondence: Fanougbo Avoce Viagannou, ENEAM of University of Abomey-Calavi, LEP- Laboratory of \\ Public Economy, PO Box: 05 BP 1652 Cotonou, Benin. Tel: 229-9744-3459; 9452-5266. E-mail: \\ fanougboisaac2@yahoo.com; fanougbo.viagannou@eneam.uac.bj
}

Received: December 30, 2020

doi:10.5539/jsd.v14n2p14

\author{
Accepted: January 30, 2021 \\ Online Published: February 3, 2021 \\ URL: https://doi.org/10.5539/jsd.v14n2p14
}

\begin{abstract}
The issue of agricultural sustainability remaining a topical concern. While agriculture being an important sector for the development of world economies. It has noted that implementing farming sustainably for a better contribution in the next generation economic development needed. The main purpose of this paper is to analyze the economic sustainability of the rice farms and market gardening benefiting from the FAFA MC project in the Southwest juxtaposed departments in Benin. Specifically, it is first of all a question of assessing, with regard to the two types of farms, which type of farming is the most sustainable. Next, to see whether rice farms are more sustainable than market gardening farms; and finally, to highlight the relationship between economic sustainability and environmental and social sustainability. The data used where obtained from FAFA MC database (2012). Finally, a data of 48 farms were used in the analysis. The analysis techniques have consisted of three steps these are: descriptive analysis, the principal component analysis applied and an ascending hierarchical classification applied. The analysis of data supported by SPSS 2.0, Excel 2013 and SPAD 5.5 software package. To understand the economic sustainability of the farms, the sustainability indicators methodology of IDEA was employed. Overall, it emerges from the analysis of results that the farms considered have limited economic sustainability (a score of 38.25 / 100); group farms prove to be more economically sustainable than individual farms and vegetable farms are more economically sustainable compared to rice farms. So, it seems important to encourage groupings of individual farmers, to clearly define property rights on agricultural land, to sensitize producers to the application of the principles of sustainable development.
\end{abstract}

Keywords: economic sustainability, sustainable agriculture, sustainable development, market gardening, rice farms, principal component analysis, Benin

\section{Introduction}

From a neoclassical point of view, sustainable development (SD) which helps maintain global capital, seems to prevail. Indeed, Martinet (2012) presents all of the debates relating to the economic theories of SD. Already, Solow (1993) showed that there is an optimal growth trajectory that integrates global capital as a constant. Thus, by considering an extension of this capital to natural capital, we obtain the first neoclassical approach to SD which translates to "low sustainability". As a result, Beckerman (1994) speaks of sustainable growth by considering that growth and development are merged. Along these lines, technical progress makes it possible to produce substitutes; and therefore, the depletion of exhaustible natural resources is offset by an increase in the relative prices of these resources. In this logic, growth is considered to be sustainable. For some authors (Pearce \& Atkinson, 1993) this substitution has some limits, for example due to the absence of a substitute for biodiversity. For these authors, the environment provides not only raw materials, but also finished products. This logic translates the concept of "strong sustainability" which implies that the state must intervene to avoid "let it go". This position is more accentuated in Daly (1999). For the classics, sustainable development is to maintain total capital, whilst finding substitutes for destroyed natural capital. In the approaches of ecological economics, we note a position qualified as conservative of nature. Thus, for this current, the preservation of nature for future generations, constitutes a major concern.

In view of the above, the sustainability of agriculture is becoming a major challenge for economies. Agriculture 
being an important sector for the development of most African economies; it must be carried out sustainably for a better contribution to sustainable development. Thus, farms must have characteristics that meet the constraints of sustainable agriculture. The complexity of measuring the level of sustainability of agriculture is well mentioned by Wrzaszcz and Zegar (2014). It is the same about of the economic sustainability of agriculture. This sustainable agriculture, according to Francis and Youngberg (1990), constitutes an ecologically healthy, economically viable, socially just and humane agriculture. As for the idea of Gafsi (2006), sustainable agriculture takes into account two elements: (i) the viability of a farming system or "self-centered sustainability", (ii) the contribution of the farming system to the sustainability of the territory. Research in agrarian economics has long focused on the technical and economic performance of farms to compare production systems with each other and to think about development projects. Applied to farming, Zahm and Mouchet (2013) define the overall performance of a farming operation as its level of contribution to sustainable agriculture. Analysis of the many definitions and principles underlying the concept of sustainable agriculture shows a plurality of approaches and scales. Among these definitions, the definition of Francis and Youngberg (1990) is the one that seems the most in agreement with the various general principles of social responsibility. This social responsibility is described in the context of current companies (Kleine \& von Hauff, 2009).

The issue of agricultural sustainability remains a topical concern. The concept of sustainable agriculture is presented as an application of sustainable development in the agricultural sector. A recent diagnosis of the agricultural sector in Benin shows that the sector is dominated by small family-type farms orientated towards mixed farming. These farms have an average area estimated at 1.7 hectares (MAEP, 2016). Of the 11 million hectares of gross surface area available, almost $60 \%$ is suitable for agriculture. Of all the possible uses of the earth's surface, agriculture occupies most of the territory. In fact, in Benin, agriculture is the most important sector of the economy and provides income for around $75 \%$ of the working population. Therefore, the agricultural sector is of capital importance for the strengthening of the Beninese economy, because it contributes on average $32.5 \%$ to the GDP, $75 \%$ to export revenues, $15 \%$ to state revenues and provides around $70 \%$ of jobs (MAEP, 2015). Agricultural activity is therefore strongly linked to the sustainability of the territory. As a result, the conduct of sustainable agriculture becomes essential in order to preserve the resources of rural areas for future generations. Indeed, the concept of sustainable agriculture, application of the principles of sustainable development to the agricultural sector, tries to take into account all of the economic, social and environmental dimensions and to define a global framework. In Ba and Aubry (2011), the concept of double sustainability is even approached at the level of urban farms. For them, the first criterion of internal sustainability is the economic viability of the operation. In this context, assessments of the value of farms are made and compared to investments. Also, they took into account the criteria of livability, workload and transmissibility. They were also interested in environmental sustainability; whilst taking the example of water used for production. The quality of this resource constitutes a risk factor for the production system considered (Yang et al., 2018).

However, the concept of sustainability remains rather vague and raises questions. How can we assess the sustainability of a farm? The methods which are used for the sustainability of agricultural holdings can be evaluated from a construction which rests on three axes of sustainability namely the agro-ecological, socio-territorial and economic axes. This construction is based on several methods. One of these, the farming sustainability indicators (IDEA) method, makes it possible to assess the sustainability of farms using indicators. De Castro and al. (2009) find that it is necessary to assign points to the farm according to given measurable criteria and for each indicator. Thus, a comparison is made between agricultural systems based on graphical representations of the calculated scores. Based on the IDEA method, M'Hamdi and al. (2009) assess the sustainability of 30 dairy farms in Tunisia. Their study was based on the three sustainability scales (socio-territorial, agro-ecological and economic) using PCA and AHC statistical methods. Specifically, by focusing on the economic scale, their study shows that economic sustainability is characterized by good efficiency and varies according to the degree of financial autonomy. For these authors, the evaluation of the overall sustainability of a farm requires an analysis of the interdependencies between the three sustainability scales. Ghozlane and al. (2010) focus on the assessment of the sustainability of 83 farms in Algeria using the IDEA approach. Their assessment took into account the three sustainability scales and their factor analysis revealed four groups of farms. From a sustainability point of view, their study shows that the best performances are recorded on the economic and socio-ecological scales whilst the socio-territorial scale limits total sustainability. Specifically, with regard to the economic scale, it should be noted that the components "independence", "transmissibility" and "efficiency" enabled this scale to reach an average value of around $54.7 \%$.

In Benin, agricultural production is the foundation of the economy. Among the farms, rice and market gardening are of paramount importance because of the importance of their products in the eating habits. In terms of vegetable 
production, the Adja area in Couffo (a department in the southwest) comes in third place, after the extreme north and northeast out of the five major production areas in the country (Yehouenou, 2011); the peri-urban areas, including Mono (a department in the southwest), come in fifth place, after the southeast area. And as Savi (2009) recognized and taken up by Komlan et al (2013), the municipalities of Houéyogbé and Dogbo in the Mono-Couffo departments in the south-west constitute favorable areas to market garden production, in which several actors are launching themselves. With regard to rice, Balaro et al (2014) show that Benin has a significant potential for rice production. For these authors, the ecological conditions (temperature, soil type, height and distribution of rainfall), as well as the hydro-agricultural potential (flood plains and lowlands) enable them to credit Benin with significant and sustainable rice production. Rice production is more concentrated in the central and northern departments; the other departments including Mono and Couffo contribute marginally (Balaro et al., 2014). In fact, within the framework of the promotion of agricultural sectors, the main axis of the policy of revival of the agricultural sector in Benin, the FAFA project (Facility for Support to Agricultural Sectors in the Mono and Couffo Departments (FAFA MC)), which is a project of the Beninese-Belgian cooperation, has been set up. FAFA MC is implemented by the Ministry of Agriculture, Livestock and Fisheries (MAEP) and the Belgian Technical Cooperation (BTC). Its specific objective is to "strengthen the capacities and effective articulation of private and public actors in order to improve the productivity and profitability of the rice and market gardening sectors in Mono-Couffo". It should be noted that the context in which the FAFA MC project came into being is that national rice production covers about $30 \%$ of Benin's needs. The departments of Mono and Couffo, contribute in the order of 5 to $6 \%$. Rice production is practiced by a very small minority of farmers in Mono-Couffo (3\%) cultivating an average of 0.5 ha of rice per farmer (FAFA, 2009). The FAFA MC project naturally takes into account the rice and market gardening sectors in the Mono and Couffo departments, two sectors that correspond to the intensification strategies of small producers and that have proven potential and opportunities. The departments of Mono and Couffo, contribute in the order of 5 to $6 \%$. Rice production is practiced by a very small minority of farmers in Mono-Couffo (3\%) cultivating an average of 0.5 ha of rice per farmer (FAFA, 2009). The FAFA MC project naturally takes into account the rice and market gardening sectors in the Mono and Couffo departments, two sectors that correspond to the intensification strategies of small producers and that have proven potential and opportunities. The farms supported by FAFA MC (Mono-Couffo) fall into two categories: individual farms and group farms. After having benefited from FAFA support, these various farms must remain economically sustainable. The economic sustainability of the latter allows to perpetuate the achievements resulting from the implementation of FAFA. An analysis of this economic sustainability is therefore necessary for the farms available in the FAFA database. Generally speaking, one may ask: are the farms in the FAFA database economically sustainable? Specifically, one wonders whether: (i) are group farms more sustainable than individual farms in FAFA MC? (ii) are rice farms more sustainable than market gardening farms with FAFA MC? (iii) Does FAFA MC generate economic sustainability in relation to environmental and social sustainability?

In order to address the above concerns, the objective of this paper is to analyze the economic sustainability of the rice and vegetable farms benefiting from the FAFA project in the Southwest departments (Mono and Couffo) in Benin. Specifically, it is first of all a question of assessing, with regard to the two types of farms, which type of farming is the most sustainable. Next, to see whether rice farms are more sustainable than market gardening farms; and finally, to highlight the relationship between economic sustainability and environmental and social sustainability. Indeed, the second section of this paper presents the methodological approach followed. The results and discussion are developed in the third section. The final section deals with the conclusion.

\section{Methodological Evaluation Process}

\subsection{Synthesis on Sustainability Assessment Methods}

The evaluation of sustainability in agriculture involves methods based on indicators. Developed by a group of researchers, teachers and technicians, the IDEA method allows on the one hand, to formalize the theoretical framework of the concept of sustainable farming and then, in a sustainable farming approach, to assess the level overall operating performance on the other hand. The scientific construction of the IDEA method required a number of steps developed by Vilain et al. (2008); Zahm et al. (2008). As for the general scientific approach chosen for the construction of the various indicators, it followed the steps proposed by Girardin et al. (1999).

At the level of this IDEA method, the sustainability of a farm is first defined in a self-centered approach to sustainability. According to Landais (1998), a farm is sustainable if it is viable, livable, transmissible and reproducible. In its scientific construction, the IDEA method assesses the sustainability of a farm according to a triple bottom queue approach structured in 3 sustainability scales and 17 objectives qualified by 42 indicators grouped in within 10 components. The 17 objectives selected made it possible to formalize the assumptions of the sustainability model and to expose the determinants of overall performance. Apart from the IDEA method, it should 
be noted that other methods allow the evaluation of economic sustainability. Indeed, among other methods, Van Calker and al. (2005) used a three-step set of indicators to assess the sustainability of dairy farms. According to their method, only one indicator is retained for the evaluation of economic sustainability; it is the profitability appreciated by the net farm income. Before these authors, Hanus (2004) based his analysis of the sustainability of agricultural systems on indicators already. His method considers three levels of sustainability. The economic sustainability assessed in this case is basically based on the gross margin which indicates the level of stability of the system. Ultimately, this paper focuses on the IDEA method. Indeed, this method takes a holistic approach to the sustainability of farming systems. It makes it possible to determine the sustainability of a farm from a geographical and temporal point of view. It also seems relevant because it allows for a balanced diagnosis at the level of SD dimensions. These arguments support his choice to study the economic sustainability of rice and vegetable farms that benefited from the FAFA MC project.

\subsection{The Economic Sustainability Assessment Approach}

\subsubsection{Data}

The Ministry of Agriculture, Livestock and Fisheries and the Belgian Technical Cooperation initiated the project "Support Facility for Agricultural Sectors in the Departments of Mono and Couffo (FAFA MC)" from 2009 to 2013. Its objective is to "strengthen the capacities and effective articulation of private and public actors in order to improve the productivity and profitability of the rice and market gardening sectors in Mono-Couffo". But in 2012 for an evaluation phase conducted jointly by the two institutions, the project took into account 48 farms in the Vegetable and Rice sectors in the departments concerned. The database produced for this purpose contains the data used in this document. The variables used to collect the information from these producers include the area of land, FAFA subsidies, the price of one hectare of land, the cost of agricultural land etc. In the database, out of the 48 farms concerned, 31 are from Mono (17 vegetable farms and 14 rice farms) then 17 from Couffo (11 vegetable farms and 06 rice farms). It has 21 group farms ( 16 from Mono ant 5 from Couffo), 27 individual farms (15 from Mono and 12 from Couffo).

\subsubsection{Variables}

The paper discusses the economic scale of sustainability. The aim of this scale is to: control costs and investments, increase added value, assess dependence on aid, reduce vulnerability to the market, consolidate and secure income, promote gearbox. The different components selected by the IDEA method for the scale of economic sustainability are: economic viability, economic and financial independence, transmissibility and efficiency of the productive process. Table 1 presents these different components according to Vilain et al. (2008).

The IDEA method is a scoring method that measures the level of sustainability of agricultural systems from 42 indicators structured in three sustainability scales (agro-ecological, socio-territorial and economic). Each sustainability scale is subdivided into three or four components which summarize the basic characteristics of the sustainability diagnosis. The economic scale, on which this paper has focused, has six indicators divided into four components as mentioned in table 1.

Table 1. Components of the economic sustainability scale of the IDEA method

\begin{tabular}{lllcl}
\hline & & & Economic scale \\
\hline Components & & \multicolumn{1}{c}{ Indicators } & Maximum score \\
\hline Viability & C1 & Economic viability & 20 & 30 units \\
& C2 & Economic specialization rate & 10 & \\
\hline Independence & C3 & Financial autonomy & 15 & 25 units \\
& C4 & Aid sensitivity & 10 & \\
\hline Transmissibility & C5 & Capital transferability & 20 & 20 units \\
\hline Efficiency & C6 & Efficiency of the productive process & 25 & 25 units \\
\hline Total & & & & 100
\end{tabular}

Source: Vilain et al. (2008)

The calculations of the various indicators have been carried out. After, the associated scores are obtained according 
to the criteria defined by the user guide of the IDEA method. Specifically, with regard to transmissibility, it should be noted that it is observed in tropical Africa from father to son or between members of the same family. Indeed, for a farm to be economically transferable it would have to be economically viable and the family labor force would be significant. The methods for calculating the scores for this indicator are therefore developed by Ahoungninou (2013).

\subsubsection{Analysis Techniques}

First, a descriptive analysis of the data is made to understand the characteristics of the producers. Subsequently, we carried out a Principal Component Analysis by considering the scores obtained for the different indicators as active variables. Finally, an Ascending Hierarchical Classification is made in order to obtain homogeneous groups of individuals. SPSS 20, Excel 2013 and SPAD 5.5 software were used.

\section{Results and Discussion}

\subsection{Statistical Results}

\subsubsection{Socio-Demographic Statistics}

This section presents the statistical results. Indeed, Table 2 presents the socio-demographic statistics of the respondents from the database used.

Table 2 shows that the age of farm managers varies between 35 and 76 years with an average of 48 years; the majority of respondents (52.1\%) are between 45 and 49 years old. The proportion of women in the base is $31.3 \%$ compared to $68.8 \%$ for men. The farms which practice market gardening are dominant $(58.3 \%)$ and the rest of the farms $(41.7 \%)$ produce rice.

Table 2. Socio-demographic characteristics of producers

\begin{tabular}{lllllll}
\hline & \multicolumn{2}{l}{ Department of Mono } & \multicolumn{2}{l}{ Department of Couffo } & \multicolumn{2}{c}{ Together } \\
\hline & Number & $\%$ & Number & $\%$ & Number & $\%$ \\
\hline Age (year) & & & & & & \\
\hline $35-44$ & 9 & 29.0 & 4 & 23,5 & 13 & 27.1 \\
$45-49$ & 18 & 58.1 & 7 & 41.2 & 25 & 52.1 \\
$50-76$ & 4 & 12.9 & 6 & 35.3 & 10 & 20.8 \\
\hline Literate & & & & & & \\
\hline No & 7 & 22.6 & 8 & 47.1 & 15 & 31.3 \\
Yes & 24 & 77.4 & 9 & 52.9 & 33 & 68.8 \\
\hline Sex & & & & & & \\
\hline Feminine & 8 & 25.8 & 7 & 41.2 & 15 & 31.3 \\
Male & 23 & 74.2 & 10 & 58.8 & 33 & 68.8 \\
\hline Type & & & & & \\
\hline Group & 16 & 51.6 & 5 & 29.4 & 21 & 43.8 \\
Particular & 15 & 48.4 & 12 & 70.6 & 27 & 56.3 \\
\hline Agricultural sector & & & & & \\
\hline Market gardening & 17 & 54.8 & 11 & 64.7 & 28 & 58.3 \\
Rice & 14 & 45.2 & 6 & 35.3 & 20 & 41.7 \\
\hline
\end{tabular}

Source: Author, from data FAFA 2012

\subsubsection{Average Scores for Indicators and Components}

The average scores of the indicators and components of the economic scale are determined in accordance with the IDEA methodology. Table 3 presents these average scores, as well as the overall scores for each type of farm, for each sector and for each department. 
Table 3. Average scores of indicators, components and economic scale by category

\begin{tabular}{|c|c|c|c|c|c|c|c|c|}
\hline \multirow[b]{3}{*}{ Indicators } & \multicolumn{8}{|c|}{ Scores Averages } \\
\hline & \multicolumn{2}{|c|}{ Type } & \multicolumn{2}{|c|}{ Sex } & \multicolumn{2}{|c|}{ Agricultural sector } & \multicolumn{2}{|c|}{ Department } \\
\hline & Particular & Group & Male & Feminine & Rice & Market gardening & Mono & Couffo \\
\hline Economic viability & 0.89 & 2.90 & 1.97 & 1.33 & 2.90 & 0.96 & 1.19 & 2.82 \\
\hline Specialization rate & 1.41 & 0.76 & 0.97 & 1.47 & 0.40 & 1.64 & 0.97 & 1.41 \\
\hline Financial autonomy & 15,00 & 15.00 & 15.00 & 15.00 & 15.00 & 15.00 & 15.00 & 15.00 \\
\hline Aid sensitivity & 3.26 & 1.90 & 2.91 & 2.13 & 3.90 & 1.79 & 2.39 & 3.18 \\
\hline Transferability & 0.30 & 1.57 & 0.94 & 0.67 & 1.15 & 0.64 & 0.68 & 1.18 \\
\hline Efficiency & 16.59 & 17.14 & 16.55 & 17.47 & 12.20 & 20.14 & 17.03 & 16.47 \\
\hline \multicolumn{9}{|l|}{ Components } \\
\hline Economic viability & 2.30 & 3.66 & 2.94 & 2.80 & 3.30 & 2.60 & 2.16 & 4.23 \\
\hline Independence & 18.26 & 16.90 & 17.91 & 17.13 & 18.90 & 16.79 & 17.39 & 18.18 \\
\hline Transferability & 0.30 & 1.57 & 0.94 & 0.67 & 1.15 & 0.64 & 0.68 & 1.18 \\
\hline Efficiency & 16.59 & 17.14 & 16.55 & 17.47 & 12.20 & 20.14 & 17.03 & 16.47 \\
\hline Global Score & 37.44 & 39.29 & 38.33 & 38.07 & 35.55 & 40.18 & 37.26 & 40.06 \\
\hline
\end{tabular}

Source: Author, from data FAFA 2012

Analysis of Table 3 reveals that the farms studied are very unsustainable (1.19 in the Mono and 2.82 in the Couffo). Note that groupings (2.90) are a little more viable than individuals (0.89).

Considering all 48 farms, Table 4 gives a presentation of the scores for the indicators and the components (the average values).

Table 4. Average values of the economic dimension indicators

\begin{tabular}{|c|c|c|c|c|c|}
\hline \multicolumn{6}{|c|}{ Economic scale } \\
\hline Components & \multicolumn{2}{|c|}{ Average scores } & \multirow{2}{*}{$\begin{array}{l}\text { Indicators } \\
\text { Economic viability }\end{array}$} & \multicolumn{2}{|c|}{ Maximum score } \\
\hline \multirow[t]{2}{*}{ Viability } & . & 1.77 & & 20 & 30 UNITS \\
\hline & 2.9 & 1.13 & Economic specialization rate & 10 & \\
\hline \multirow[t]{2}{*}{ Independence } & & 15 & Financial autonomy & 15 & 25 UNITS \\
\hline & 17.67 & 2.67 & Aid sensitivity & 10 & \\
\hline Transmissibility & 0.85 & 0.85 & Transferability of capital & 20 & 20 UNITS \\
\hline Efficiency & 16.83 & 16.83 & Efficiency of the production process & 25 & 25 UNITS \\
\hline Total & & & 38.25 & & 100 \\
\hline
\end{tabular}

Source: Author, based on indicator calculations (From data FAFA 2012)

Table 4 shows that the "viability" component has an average of 2.9 points. This average represents $9.67 \%$ of the theoretical maximum which is 30 points. Among the indicators for this component, the "economic specialization rate" indicator obtained an average of 1.13 which represents $11.3 \%$ of its theoretical maximum (10 points). This is due to the fact that these farms are for the most parting much specialized. The second indicator for this component is "economic viability". The latter obtained an average of 1.77 points which is also low compared to its maximum (20 points). This average represents $8.85 \%$ of its theoretical maximum. For this indicator, the scores ranged from 0 to 20 points. The farms constituting the database are not economically viable. These findings are linked to the small areas exploited which do not allow producers to reap high profits. As for the "independence" component, its average is 17.67 points and represents $70.68 \%$ of the theoretical maximum. The operators surveyed are financially independent but benefit from financial aid or subsidies for their production activity. Concerning the 
"transmissibility" component, the average is 0.85 points. This average represents $4.25 \%$ of the theoretical maximum which is 20 points. The farms studied are therefore poorly transmissible. The low transmissibility of these farms is explained by the low economic viability and the low number or absence of direct heirs working with the operators. With regard to the "efficiency" component, the average is 16.83 points and represents $67.32 \%$ of the theoretical maximum which is 25 points. These farms then have good efficiency. The overall score for economic sustainability of the 48 holdings in the database is also determined. All the scores relating to the components and to the 48 farms were taken into account. From the analysis of these scores, we note that the lowest score obtained for the economic sustainability scale is 24 points whilst the highest score is 67 points. The average score obtained by all farms is 38.25 points.

\subsubsection{Principal Component Analysis (PCA)}

Tables 5 and 6 respectively present the eigenvalues and the correlation coefficients. From the analysis in Table 5, it emerges that the value of the total inertia of the point cloud is 5. The first factorial axis extracts almost half of the total inertia. The share of information explained by the second axis is important since it represents a third of the total inertia. The first two factor axes summarize more than $77 \%$ of the total inertia of the cloud. These first two factorial axes allow us to continue the analysis.

Table 5. Eigenvalues

Source: Author, from data FAFA 2012

\begin{tabular}{cccc}
\multicolumn{3}{c}{ Trace of matrix: $\mathbf{5 . 0 0 0 0 0}$} & \\
\cline { 1 - 3 } $\mathbf{N}^{\circ}$ & Eigenvalues & Percentage & Cumulative percentage \\
\hline $\mathbf{1}$ & 2.2081 & 44.16 & 44,16 \\
$\mathbf{2}$ & 1.6570 & 33.14 & 77.30 \\
$\mathbf{3}$ & 0.9733 & 19.47 & 96.77 \\
$\mathbf{4}$ & 0.1245 & 2.49 & 99.26 \\
$\mathbf{5}$ & 0.0372 & 0.74 & 100.00 \\
\hline
\end{tabular}

Table 6. Matrix of correlations

\begin{tabular}{lccccc}
\hline & Economic viability & Specialization rate & Aid sensitivity & Economic transferability & Efficiency \\
\hline Economic viability & 1.00 & & & & \\
Specialization rate & 0.03 & 1.00 & & & \\
Aid sensitivity & -0.16 & -0.09 & 1.00 & & \\
Economic transferability & 0.96 & 0.02 & -0.17 & 0.11 & 1.00 \\
Efficiency & 0.10 & 0.14 & -0.87 & & \\
\hline
\end{tabular}

Source: Author, from data FAFA 2012

Analysis of the correlation matrix suggests that the linear correlation coefficient between "economic viability" and "transmissibility" is 0.96 . This means that there is a very strong and positive linear link between these two variables. Furthermore, between "efficiency" and "aid sensitivity", the correlation coefficient is -0.87 . This translates into a very strong and negative linear link between these two variables. In addition, it should be noted that the test values obtained in the cases of connection are respectively 13.71 and -9.30 . These values are greater in absolute value than 2; which justifies that the two connections are significant. A projection of the active variables in the factorial plane gives the correlation circle in figure 1.

Analysis of figure 1 clearly shows that the variables "aid sensitivity", "economic viability", "transmissibility" and "efficiency" are well represented by the factor plane formed by the first two factor axes because they are very close to the edge of the correlation circle in this plane. In addition, it is clearly seen that the variables "economic viability" and "transmissibility" are very close whilst the variables "aid sensitivity" and "efficiency" are opposite.

The observation of the point cloud (figure 2) makes it possible to distinguish three groups of individuals. Two of them are above axis 1 . One is rather to the left with a small number of relatively dispersed individuals. It is 
characterized by efficient farms, more or less viable and easily transmissible. The other is orientated to the right and characterized by farms which are not viable and are sensitive to aid. The last group is below the same axis with a large number of individuals. It is characterized by efficient farms with a low specialization rate.

An Ascending Hierarchical Classification is necessary to identify the different groups of individuals with similar characteristics.

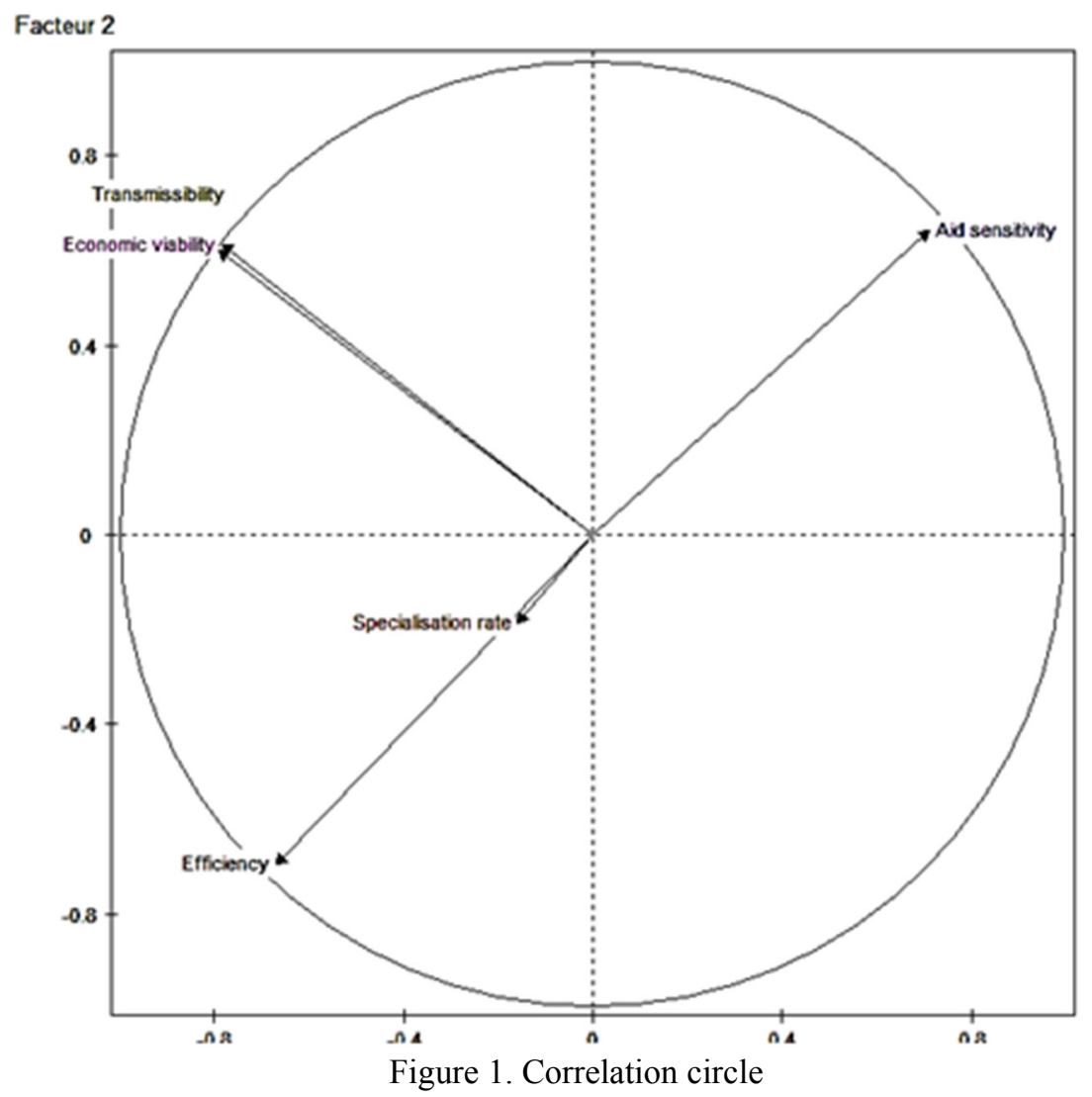




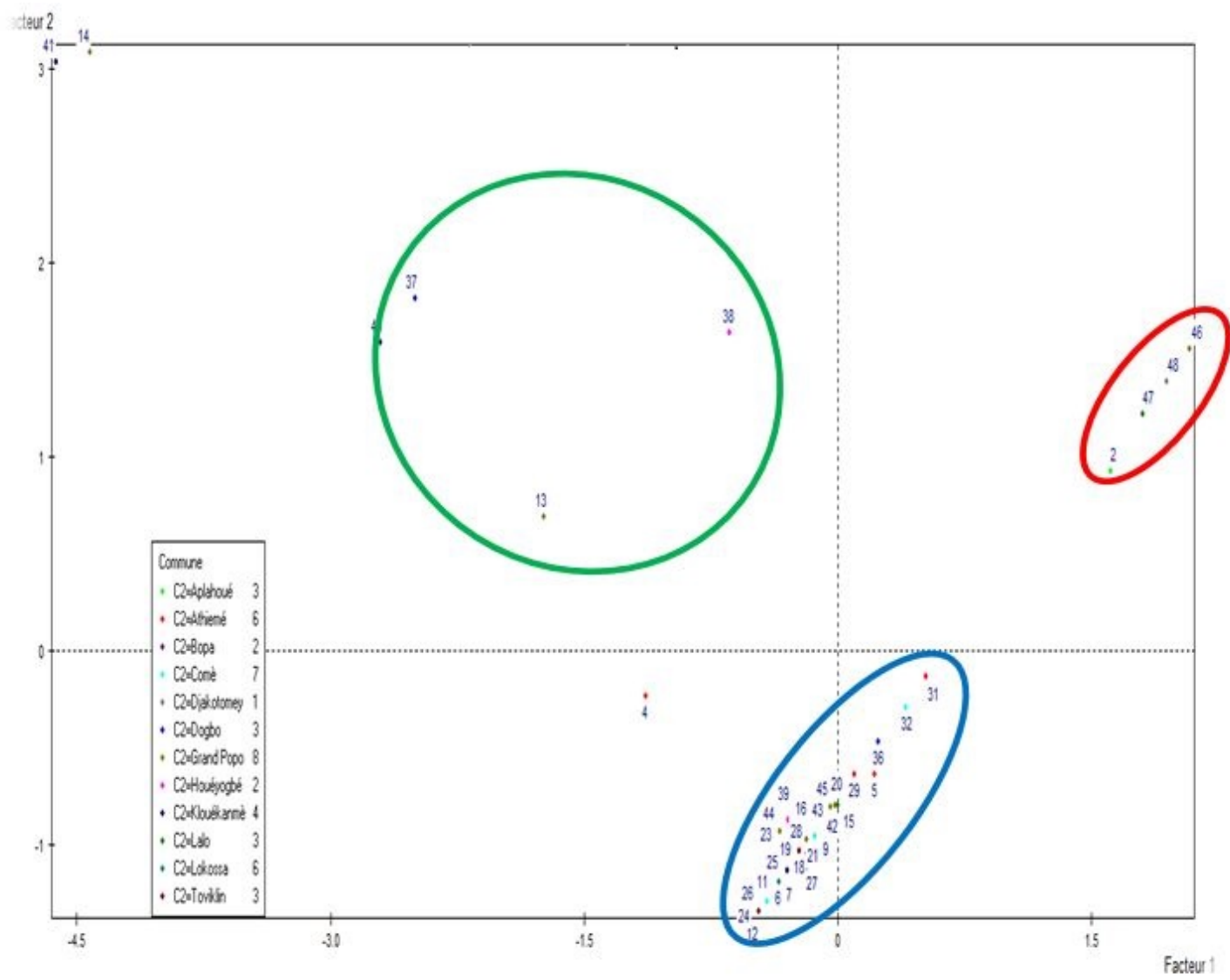

Figure 2. Point cloud

\subsubsection{Ascending Hierarchical Classification (AHC)}

The best classification is obtained for an index of 1.48; which leads to forming three classes (figure 3 ). The first class is made up of individuals who obtained good values for the "aid sensitivity" indicator and low values for the other four indicators.

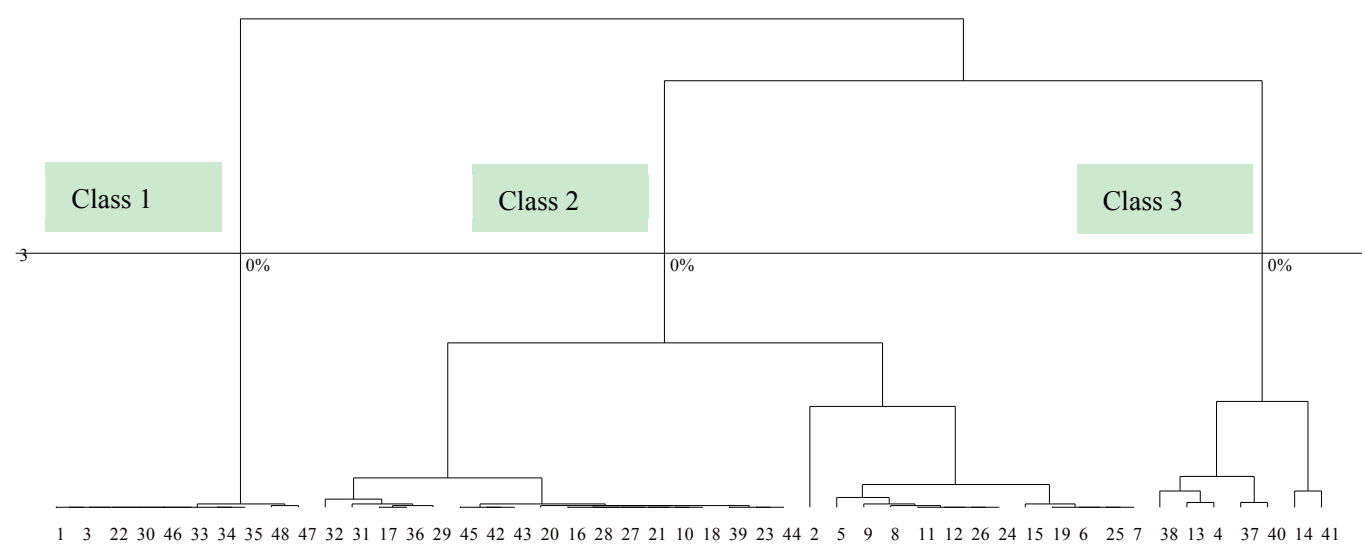

Figure 3. Ascending hierarchical classification

The second class includes a large number of individuals who obtained good values for the "efficiency" indicator 
and very low values for the "economic viability" indicator. The last class is made up of farms that are moderately viable and economically transferable and which have an efficient production process.

\subsection{Discussion}

\subsubsection{Sustainability by Type of Producer and Type of Crop Farming}

Based on the results in Table 2, the farms which are managed by groupings represent $43.8 \%$ of all the farms in the FAFA database; the remaining $56.3 \%$ are managed by individual operators. This state of affairs once again confirms the dominant behavior of individual initiatives in the creation of businesses in Benin. This corroborates with the results of De Lettenhove and Lemaitre (2018). As individual farms are dominant (56.3\%) in these departments with regard to the data used, their sustainability must be an important issue. The available database presents the farms in terms of specialization (some deal with market gardens and others with rice). This database does not mention the simultaneous cultivation of market garden products and rice. Generally, rice cultivation is done in lowlands while this is not the case in vegetable gardens. The data used does not specify whether there are operators in the two production sectors. In light of these statistics, can we say that individual farms are more sustainable than those of groups? or are rice farms more sustainable than market gardens?

Based on the results in Table 3, groupings are more economically viable than individuals. The appreciable viability at the group level stipulates that the groups are more efficient economically than the individuals. This state of affairs can be explained by the fact that at the level of groups, the cost of production is reduced due to mutualist or team work within them. Group farms were found to be more efficient (17.14) than individual farms (16.59); and reducing potential production costs and meeting production targets. Likewise, mutualism means that the need for financing would be reduced in groups compared to individuals. It should also be noted that individual farms (3.26) are more sensitive to aid than groups (1.90). In fact, groups are generally more likely to benefit from financial support compared to individuals; which makes them seem to be more financially independent. Focusing on the overall sustainability score of the economic scale, group farms appear to be more sustainable (39.29) compared to individual farms (37.44). Thus, group farms are a way to raise awareness of group initiatives.

On the other hand, we note that the rice farms have a better viability (2.90 against 0.96$)$ and are more sensitive to aid compared to vegetable farms (3.90 against 1.79). This situation in terms of viability challenges for vegetable farms, remains relevant even if the study areas are not identical (Ayedegue \& Degla, 2020). It should also be noted that market gardening systems are much more efficient (20.14) than rice systems (12.20). This efficiency would result from the diversification of farms in terms of market garden products on the same area. Regarding the overall sustainability score for the economic scale, the Couffo farms are slightly more economically sustainable compared to those of the Mono (40.06 versus 37.26). It is the same for market gardening (40.18) compared to rice cultivation (35.55). The agricultural diversification of a farm seems to strengthen its stability in the face of economic constraints. Thus, vegetable farms almost always have diversified products (tomatoes, peppers, carrots, etc.); which is not generally the case with rice farms. Also, it should be noted that the two study areas are such that the Mono is a coastal area and the non-coastal Couffo is juxtaposed with the Mono towards the interior. These elements relating to diversification at the farm level and the geographical position of the study areas partially justify these results on economic sustainability. These results provide policy guidance on the crops under consideration.

\subsubsection{Overall Economic Sustainability of Farms}

From the analysis of Tables 3 and 4, the results show that the agricultural holdings constituting the database are not economically viable. These findings are linked to the small areas exploited which do not allow producers to reap high profits. These farms are therefore not very transmissible. This is due to the low economic viability and the small number or absence of direct heirs working with the operators. In addition, the operators surveyed by the project are financially independent and benefit from financial aid or subsidies for their production activity. The farms studied are very specialized, which weakens their stability in the face of economic constraints. These farms also have good efficiency as in the case of M'Hamdi et al. (2009), which translates into economical management of available resources. As for the overall score for economic sustainability, it varies between 24 and 67 points with an average of 38.25 points out of 100 . This value is far below the average. Consequently, all of these holdings have low economic sustainability. In addition, with regard to the analysis of the results of Principal Component Analysis (PCA) and Ascending Hierarchical Classification (AHC), the economic sustainability of market gardening and rice farms in the departments of South-West Benin depend strongly on the variables "Independence" and "Efficiency", then weakly on the variables "Transmissibility" and "Economic viability". Indeed, the efficiency of the productive system combined with financial independence reinforces economic sustainability in these sectors. The negative correlation between "aid sensitivity" and "efficiency" suggests that financial aid should be reduced to increase the efficiency of the productive system. Thus, economic sustainability would be strengthened by the 
weakness of financial aid. Financial autonomy makes these farms more efficient. By making the farms larger in size, the farms would be more economically sustainable. An innovative strategy in the production system of its sectors is necessary. Moreover, in the work of Läpple and Thorne (2019) a fundamental determinant of the economic sustainability of Irish dairy farms is identified. Indeed, they show that innovation acts positively on economic sustainability in a non-linear way; in other words, they find that the economic gains come from the level of innovation. For them, in order to achieve an economically sustainable expansion of the dairy sector, popularization of the promotion and adoption of innovative technologies and practices is required. Although their sector is not identical to the present case, a reorganization of agricultural activities in the South-West of Benin is fundamental. It urges to encourage the group farms whose sizes are reasonable and which have an inheritance regime for the descendants of the members, and which are a little more diversified. This no less innovative strategy is an asset for achieving the economic sustainability of farms in the departments of Couffo and Mono, for a better contribution to the process of sustainable development in Benin.

\subsubsection{Economic Sustainability and Social and Environmental Challenges}

It is true that this paper looks fundamentally at the economic sustainability of rice and vegetable farms in the departments of Mono and Couffo in Benin. But it is important to appreciate how this economic sustainability strengthens the achievement of environmental and social objectives in terms of sustainable development. In their recent work, Ayedegue and Degla (2020) allude to socio-territorial sustainability that attempts to link the economic and the social. Indeed, social sustainability stipulates that the stocks of human and social capital that would be passed on to future generations are at least equal to the average level available per capita in the present. And the positive mechanisms of social capital evoked by Callois (2004) make it possible to achieve interesting economic results. Indeed, in the farms of rice and market gardening groups, these mechanisms strengthen the results in terms of gross operating surplus, and consequently improve economic viability. The different experiences acquired by belonging to the production groups increase the knowledge levels of the participants, which strengthens the human capital, thus allowing an improvement of the economic viability.

The search for economic sustainability at the level of rice and vegetable farms seems to act on the environmental level. These farms do not really conflict with the preservation of the environment. Avilés Benitez (2001) showed that there is not necessarily a contradiction between economic viability and the management of natural resources. The author points out that there can be a trade-off between environmental and economic objectives at the farm level. Rice and market gardening are practically renewable natural resources. The ecosystems that can be observed at the level of rice farms are maintained. But in a context where farmers would use chemical fertilizers, there may be some threats to certain species of the ecological system in place. The same is true for non-organic market gardening farms. Moreover, Brageon and Chitrit (1999) already explained that organic farming has a positive effect on the environment. Some risk factors can be observed in the case of the use of pesticides.

Ultimately, strengthening the economic sustainability of farms lies in part in the search for ecological and social balance. For example, the more agricultural lands are less and less polluted by the use of toxic products, the more they will lead to more efficient and economically viable farms.

\section{Conclusion}

This paper analyzed the economic sustainability of market gardening and rice farms supported by the FAFA project in the Mono and Couffo departments of southwest Benin. The evaluation phase of this project was based on 48 farms. The database developed within this framework was used for this economic sustainability analysis. The economic sustainability of the 48 vegetable and rice farms in the Mono and Couffo departments is assessed using the IDEA method. Socio-demographic statistics, Principal Correspondence Analysis and Ascending Hierarchical Classification were used to deepen the analysis of economic sustainability.

First, the study shows that the data used present two categories of farms, namely: group farms and individual farms, whether they are rice or vegetable farms. The processing of these data provides results that show that group farms prove to be more economically sustainable than individual farms. It is worth mentioning that group farms, whether rice or vegetable farms, generate large gross farm surpluses, thus strengthening economic viability, which in turn has an impact on sustainability. Also, based on the commodity chains, vegetable farms are more economically sustainable compared to rice farms. This would result from the diversification of these vegetable farms and the characteristic of the area where they are grown in abundance. Then, overall, it emerges from the analysis that the farms considered have limited economic sustainability. The low level of sustainability obtained below average is ensured by the appreciable scores of the "Independence" and "Efficiency" components. The components "Transferability" and "Economic Viability" significantly reduce this economic sustainability. The farms studied will show a significant economic sustainability if the "Transferability" and "Economic Viability" components are 
strengthened. Finally, the economic sustainability of the farms does not present any conflict with the environmental and social components. Strengthening the economic sustainability of farms is actually based on an ecological and social balance. The different farming practices make it possible to improve the stock of human and social capital while respecting nature.

It seems important to encourage groupings of individual farmers in order to have farms of reasonable size and with a high gross operating surplus; this would help to improve economic viability. Also, it is necessary to clearly define property rights on agricultural land in order to include the notion of inheritance; this would help to support transmissibility. Likewise, taking into account the social and environmental dimensions, for example through the practice of organic farming, with the accumulation of assets, would help to have economically more sustainable farms.

In short, an awareness of farmers to the principles of sustainable development would make it possible to have sustainable agriculture in general in the area; and thus, contribute to the sustainable development of Benin. A continuous analysis of these types of farms would be useful for other geographical areas with new databases and integrating other possible indicators in addition.

\section{References}

Ahoungninou, C. C. A. (2013). Durabilité de la production maraichère au Sud-Bénin: un essai de l'approche écosystémique. (Unpublished doctoral dissertation), Université d'Abomey-Calavi.

Aviles Benitez, A. (2001). Gestion des ressources naturelles et viabilité des exploitations agricoles. Le cas de l'agriculture de dehesa en Andalousie. Économie rurale, (263), 48-62.

Ayedegue, D. P., \& Degla, P. K. (2020). Durabilité socio-territoriale des exploitations maraîchères productrices de tomate au Nord Bénin. Agronomie Africaine, 32(2), 221-237.

Ba, A., \& Aubry, C. (2011). Diversité et durabilité de l'agriculture urbaine: une nécessaire adaptation des concepts? Norois, Environnement, Aménagement, Société, 221, 11-24. https://doi.org/10.4000/norois.3739

Balaro, G., Soule, B. G., \& Gansari, S. (2014). Analyse des politiques et stratégies mises en æeuvre par l'Etat dans la filière riz depuis 2008. Rapport Synthèse; LARES.

Beckerman, W. (1994). Sustainable development: is it a useful concept? Environmental Values, 3, 191-209. https://doi.org/10.3197/096327194776679700

Brangeon, J.-L., \& Chitrit, J.-J. (1999). Les éléments de durabilité de l'agriculture biologique. Le Courrier de l'environnement de l'INRA. Paris: Institut national de la recherche agronomique Délégation permanente à l'environnement, pp.53-66. Retrieved from https://hal.inrae.fr/Hal-02690397

Callois, J.-M. (2004). Capital social et développement économique local: Pour une application aux espaces ruraux français. Revue d'Économie Régionale \& Urbaine, 4 octobre, pages 551 à 577.

Daly, H. E. (1999). Ecological Economics and the Ecology of Economics: essays in Criticism. Edward Edgar, Retrieved from http://www.jstor.org/stable/10.1086/431107

De Castro, J., Sanchez, D., Moruzzi, P., De Lucas, A., \& Bonaudo, T. (2009). Adaptation de la méthode française IDEA pour l'évaluation de la durabilité des exploitations agricoles de la commune de São Sao Pedro. Renc. Rech. Ruminants, 16. Retrieved from https://hal.archives-ouvertes.fr/hal-01198105

De Lettenhove, M. K., \& Lemaître, A. (2018). Micro-entreprises du secteur informel dans le Mono (Bénin): vers un approfondissement à travers une approche d'économie populaire. Mondes en développement $\mathrm{n}^{\circ} 181, \mathrm{p}$. 11-25. https://doi.org/10.3917/med.181.0011.

FAFA. (2009). Plan d'Action Stratégique. MAEP \& CTB.

Francis, C. A., \& Youngberg, G. (1990). Sustainable agriculture-an overview. In C. A. Francis, C. B. Flora, \& L. D. King (Eds.), Sustainable Agriculture in Temperate Zones. New York, John Wiley \& Sons.

Gafsi, M. (2006). Exploitation agricole et agriculture durable. Cahiers Agricultures, 15(6). https://doi.org/10.1684/agr.2006.0035

Ghozlane, F., Belkheir, B., \& Yakhlef, H. (2010). Impact du Fonds National de Régulation et de Développement Agricole sur la durabilité du bovin laitier dans la Wilaya de Tizi-Ouzou (Algérie). NEW MEDIT N 3.

Girardin, P., Bockstaller, C., \& Werf, H. V. (1999). Indicators: Tools to Evaluate the Environmental Impacts of Farming systems. Journal of Sustainable Agriculture, 13, 5-21. https://doi.org/10.1300/J064v13n04_03

Hanus, L. (2004). Sustainability analysis of agricultural systems. Acta universitatis agriculturae et silviculturae 
mendelianae brunensis, 52(1), 103-112. https://doi.org/10.11118/actaun200452010103.

Kleine, A., \& von Hauff, M. (2009). Sustainability-Driven Implementation of Corporate Social Responsibility: Application of the Integrative Sustainability Triangle. Journal of Business Ethics, 85, 517-533.

Komlan, C., Adegbola P., Adegbidi, A., Adetonah, S., \& Mensah, G.-A. (2013). Analyse des systèmes de commercialisation de la corète potagère (Corchorus olitorius L.) produite à Agbédranfo au Sud-Ouest du Bénin (Département du Couffo). 4th International Conference of the African Association of Agricultural Economists, Hammamet, Tunisia.

Landais, E. (1998). Agriculture durable: les fondements d'un nouveau contrat social? Le Courrier de l'environnement de l'INRA, 33(33), 5-22. Retrieved from https://hal.archives-ouvertes.fr/hal-01204654

Läpple, D., \& Thorne, F. (2019). The Role of Innovation in Farm Economic Sustainability: Generalised Propensity Score Evidence from Irish Dairy Farms. Journal of Agricultural Economics, 70(1), 178-197.

M'Hamdi, N., Aloulou, R., Hedhly, M., \& Hamouda, M. B. (2009). Évaluation de la durabilité des exploitations laitières tunisiennes par la méthode IDEA. Biotechnol. Agron. Soc. Environ., 13(2), 221-228.

MAEP. (2015). Rapport de performance du secteur agricole, gestion 2015, Cotonou.

MAEP. (2016). Rapport de performance du secteur agricole, gestion 2016, Cotonou.

Martinet, D.-V. (2012). Economic Theory and Sustainable Development: What Can We Preserve for Future..... Routledge, $210 \mathrm{p}$.

Pearce, D. W., \& Atkinson, G. D. (1993). Capital theory and the measurement of sustainable development: an indicator of "weak" sustainability. Ecological Economics, 103-108, https://doi.org/10.1016/09218009(93)90039-9

Savi, A. (2009). Analyse de la rentabilité financiere et de l efficacité économique de la production du crincrin (Corchorus olitorius) dans la vallée du Mono (Unpublished master's thesis). FSA/Université d'AbomeyCalavi, 93 p.

Solow, R. (1993). An almost practical step toward sustainability. Resources Policy, 19(3), 162-172. Retrieved from https://www.jstor.org/stable/43623526

Van Calker, K. J., Berentsen P. B. M., Giesen, G. W. J., \& Huime, R. B. M. (2005). Identifying and ranking attributes that determine sustainability in Dutch dairy farming. Agriculture and Human Values, 22, 53-63.

Vilain, L., Boisset, K., Girardin, P., Guillaumin, A., Mouchet, C., Viaux, P., \& Zahm, F. (2008), La méthode IDEA Indicateurs de durabilité des exploitations agricoles, 3e édition actualisée, Ed. Educagri, Dijon, 184 p.

Wrzaszcz, W., \& Zegar, J. S. (2014). Economic sustainability of Farms in Poland. European Journal of Sustainable Development, 3(3), 165. https://doi.org/10.14207/ejsd.2014.v3n3p165

Yang, Q., Li, Z., Lu, X., Duan, Q., Huang, L., \& Bi, J. (2018). A review of soil heavy metal pollution from industrial and agricultural regions in China: Pollution and risk assessment. Environment, 642, 690-700.

Yehouenou, L. S. M. (2011). Rentabilité financière de la production du chou pommé (Brassica oleracea) et du piment (Capsicum frutescens) sous filet anti-insectes dans les départements Mono et Couffo., (UnThèse d'ingénieur agronome, Université d'Abomey-Calavi, Cirad-Agritrop. Retrieved from https://agritrop.cirad.fr/569276/

Zahm, F., \& Mouchet, C. (2013). De la Responsabilité Sociétale d'une exploitation agricole à la mesure de sa Performance Globale. Revue de la littérature et application avec la méthode IDEA. Économie et institution CRIISEA, 2012, 18-19, p. 85 - p. 119. https://doi.org/10.4000/ei.516

Zahm, F., Viaux, P., Vilain, L., Girardin, P., \& Mouchet, C. (2008). Assessing farm Sustainability with the IDEA Method-from the concept of agriculture sustainability to case studies on farms. Sustainable Development, 16, 271-281. https://doi.org/10.1002/sd.380

\section{Copyrights}

Copyright for this article is retained by the author(s), with first publication rights granted to the journal.

This is an open-access article distributed under the terms and conditions of the Creative Commons Attribution license (http://creativecommons.org/licenses/by/4.0/). 